\title{
PERANAN LEMBAGA PENDIDIKAN DALAM MEMBENTUK KARAKTER MAHASISWA MATEMATIKA
}

\author{
Oleh: Nur Rahmah \\ Prodi Tadris Matematika FTIK IAIN Palopo \\ E-mail: nurrahmah@iainpalopo.ac.id
}

\begin{abstract}
Abstrak:
Pembangunan karakter (character building) di dunia kampus, terutama di perguruan tinggi $(P T)$, dilatarbelakangi oleh maraknya penyimpangan yang terjadi di ranah publik. Disorientasi nilai maupun disharmonisasi pada tataran kehidupan masyarakat kerap ditemukan. Selain itu, di tataran elite, ragam tindakan nirketeladanan dipertontonkan seperti perilaku koruptif. Dari perspektif sosial, budaya malu perlahan-lahan mulai hilang. Belum lagi sikap tak menghargai orang lain hingga timbulnya kekerasan di tengah kehidupan masyarakat. Dalam konteks kemahasiswaan, semua pemangku kebijakan terkait dihadapkan pada persoalan untuk mengembalikan nilai-nilai luhur kepada setiap mahasiswa. PT harus berkomitmen dalam mencetak lulusan yang berkarakter dan berintegritas agar mampu berkiprah dan bersaing di level global. Dengan pendidikan pembangunan karakter, diharapkan setiap lulusan kelak lebih memiliki sikap empati. Sikap empati, merupakan salah satu kualitas karakter yang dapat mengubah dunia dunia.
\end{abstract}

Kata Kunci: Peranan, Lembaga Pendidikan, Karakter Mahasiswa, Matematika

\section{PENGANTAR}

Pelajar maupun mahasiswa merupaka generasi muda yang dididik untuk menjadi insan-insan inteluktual untuk dapat mendukung pembangunan bangsa melalui pendidikan. Hal ini berkaitan dengan makna pendidikan yang merupakan suatu proses yang terjadi secara terus-menerus yang bertujuan untuk mengubah jati diri seseorang untuk lebih maju dan berkembang dalam ilmu pengetahuan. Dengan adanya perkembangan zaman, dunia pendidikan terus berubah secara signifikan sehingga banyak merubah pola pikir banyak orang, dari pola pikir yang masih sederhana menjadi lebih modern. Dengan melalui pendidikan formal diharapkan akan lebih terarah dalam memperoleh nilai-nilai kebenaran yang berlaku di dalam norma-norma kehidupan disamping mendapatkan ilmu pengetahuan yang sesuai dengan bidangnya masing-masing.

Eksistensi suatu bangsa sangat ditentukan oleh karakter yang dimiliki. Hanya bangsa yang memiliki karakter kuat yang mampu menjadikan dirinya sebagai bangsa yang bermartabat dan disegani oleh bangsa-bangsa lain. Oleh karena itu menjadi bangsa yang 
berkarakter adalah impian bangsa Indonesia. Melalui generasi muda khususnya pelajar dan mahasiswa, masa depan bangsa Indonesia dipertaruhkan untuk menjadi lebih baik. Melalui pendidikan baik formal maupun non formal karakter manusisa terbentuk. karena kalao kita bicara tentang pendidikan bukan hanya pendidikan formal akan tetapi juga pendidikan non formal.

Berbicara tentang karakter adalah berbicara tentang bangsa, tentang keunggulan sebuah bangsa, tentang keunggulannya atas bangsa lain, serta ciri pembeda (diferensiasi) yang unik (khas atau tunggal) yang dimiliki setiap bangsa. Tentunya bukan keunggulan untuk menguasai, mengintervensi apalagi menjajah, tetapi keunggulan untuk dipandang sama dan memandang setara serta saling menghargai. Hilangnya karakter akan menjadi penanda runtuhnya suatu bangsa dan bangkrutnya sebuah negara. Sebuah bangsa tanpa identitas pada akhirnya akan menjadi bangsa dengan tabiat dan karakter pengekor dan kehilangan kesempatan untuk bergantian menjadi leader bagi bangsa lain. Bangsa pengekor lebih potensial untuk menyerap muatan-muatan negatif serta selalu disibukkan dan menghabiskan seluruh waktunya dengan berbagai upaya untuk mengatasi beragam masalah yang dihadapi, bukannya membangun bangsanya.

Menjadi bangsa yang besar adalah sebuah proses yang tidak akan dapat dicapai dengan jalan pintas secara instan. Sebuah bangsa yang masih dicirikan dengan kesibukan luar biasa untuk mengatasi penurunan degradasi moral anak bangsa, mendidik bangsanya untuk bersedia bekerja keras dengan menjalani proses dan meninggalkan budaya instan serta disibukkan dengan berbagai usaha untuk menangkis serangan budaya asing yang kurang tepat bagi generasinya, merupakan bangsa yang belum siap untuk eksis dalam era informasi dan globalisasi sekarang ini. Sisi positifnya, bangsa yang demikian sudah mempunyai kesadaran dan motivasi untuk memperbaiki diri, menyimpan semangat untuk menatap hari depan yang lebih baik, tidak bersedia menjadi bangsa yang kalah dan akan berpikir untuk mencari strategi agar menjadi bangsa yang unggul. Dengan demikian, berbicara tentang karakter tidak saja berbicara tentang memperbaiki kondisi suatu bangsa dan menangkal berbagai hal negatif tetapi menyiapkan bangsa untuk menjadi leader. Terlalu sempit jika pendidikan karakter hanya disadari dan diarahkan hanya untuk memperbaiki degradasi moral tanpa mengaitkannya dengan kesempatan untuk menjadi leader dan bergantian memimpin dunia. 
3 | al-Khwarizmi, Volume III, Edisi 2, Oktober 2015, Hal. 1 -8.

\section{PEMBAHASAN}

\section{A. Perkembangan Lembaga Pendidikan Islam}

Lembaga Pendidikan Islam yang dalam hal ini dapat diwakili oleh pesantren, madrasah dan sekolah Islam. Ketiga institusi pendidikan di atas memiliki nama yang berbeda, akan tetapi memiliki pemahaman yang sama baik secara fungsional dan substansional. Secara fungsional ketiga lembaga pendidikan tersebut sebagai wadah untuk menggembleng mental, moral dan spiritual generasi muda dan anak-anak untuk dipersiapkan menjadi manusia yang berguna bagi agama, nusa dan bangsa. Sedangkan secara substansial dapadikatakan bahwa ketiga institusi tersebut merupakan panggilan jiwa spiritual seorang kyai, ustadz, guru yang tidak semata-mata didasari oleh motif materiil, tetapi sebagai pengabdian kepada Allah. Hal ini sejalan dengan tujuan pendidikan Islam yang diungkapkan oleh Al-Ghozali yaitu mendekatkan diri kepada Allah, bukan semata-mata untuk pangkat maupun bermegah-megahan (Ihsan: 2008).

1. Pesantren.

Pesantren merupakan salah satu lembaga pendidikan tertua di Indonesia dan sejarahnya telah mengakar secara berabad-abad. Sebagai lembaga pendidikan khas Indonesia, khususnya Jawa, pesantren memiliki keunikan tersendiri yang tidak dapat ditemui dalam sejarah peradaban Timur Tengah sekalipun. Menurut Nurcholis Madjid dalam buku beliau yang berjudul Bilik-Bilik Pesantren (Paramadina-Jakarta, 1997) menyebutkan, bahwa pesantren mengandung makna keislaman sekaligus keaslian (indigenous) Indonesia. Kata "pesantren" mengandung pengertian sebagai tempat para santri atau murid pesantren, sedangkan kata "santri" diduga berasal dari istilah sansekerta "sastri" yang berarti "melek huruf", atau dari bahasa Jawa "cantrik" yang berarti orang yang mengikuti gurunya kemanapun pergi. Dari sini dapat dipahami bahwa pesantren setidaknya memiliki tiga unsur, yakni; Santri, Kyai dan Asrama (pondok).(Hamidah, From: http://hildaku.blog. com/614889 diakses Jum'at 6/6/2008 jam 11.23)

Menurut Azra (2005) sejak digulirkannya kebijakan tersebut pesantren berkembang menjadi lembaga yang tidak saja mencakup dengan pendalaman masalah agama dan madrasah tetapi juga pendidikan umum. Bahkan, pesantren juga menjadi pusat pengembangan masyarakat dalam berbagai bidang sejak dari ekonomi rakyat. Pesantren tidak lagi hanya terdapat di pedesaan; 
sejak 1980-an, banyak pesantren bermunculan di kawasan perkotaan. Semua itu juga, yang membuat anak-anak lulusan pesantren, sejak 1980-an mampu berkompetisi dan sukses melanjutkan pendidikan di mancanegara; tidak hanya di negaranegara Timur Tengah, namun juga di negara-negara Barat. Mereka ini pada gilirannya memperkaya

dan memperkuat generasi baru kaum terpelajar dan intelektual Muslim di Indonesia. (Republika, Kamis, 22 Desember 2005 dalam http://ubed-centre.blogspot.com akses Senin 16/6/2008).

Pada awal era reformasi pesantren mengalami peningkatan dan mendapatkan perhatian yang baik dari pemeritah sehingga beberapa pesantren mendapatkan ekuivalensi dengan sekolah umum diakui seperti ditegaskan UU Sisdiknas 1989 sebagaimana juga kemudian masih termuat dalam UU Sisdiknas 2003.

2. Madrasah

Madrasah adalah salah satu lembaga pendidikan Islam yang penting selain pesantren. Keberadaaanya begitu penting dalam upaya meningkat kualitas Sumber Daya Manusia (SDM) dan menciptakankader-kader bangsa yang memiliki wawasan keislaman dan nasionalisme yang tinggi. Madrasah berupaya mengintegrasikan ilmu agama dan umum. Menyeimbangkan keduanya untuk menggapai kebahagiaan dunia dan akhirat. Q.S. (Al-Qasas (28): 77.

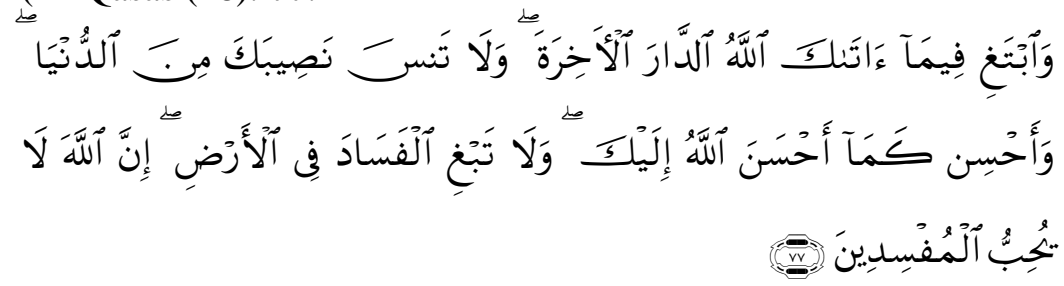

77. Dan carilah pada apa yang Telah dianugerahkan Allah kepadamu (kebahagiaan) negeri akhirat, dan janganlah kamu melupakan bahagianmu dari (kenikmatan) duniawi dan berbuat baiklah (kepada orang lain) sebagaimana Allah Telah berbuat baik, kepadamu, dan janganlah kamu berbuat kerusakan di (muka) bumi. Sesungguhnya Allah tidak menyukai orang-orang yang berbuat kerusakan.

Di Indonesia, permulaan munculnya madrasah baru terjadi sekitar abad ke-20. Meski demikian, latar belakang berdirinya madrasah tidak lepas dari dua faktor, yaitu; semangat pembaharuan Islam yang berasal dari Islam pusat (Timur Tengah) dan merupakan respon pendidikan terhadap kebijakan pemerintah 
5 | al-Khwarizmi, Volume III, Edisi 2, Oktober 2015, Hal. 1 -8.

Hindia Belanda yang mendirikan serta mengembangkan sekolah (Maksum, 1999). Berdirinya madrasah tidak terlepas dari adanya kekhawatiran terhadap sekolah-sekolah yang didirikan oleh kolonial belanda yang tidak memasukkan pelajaran agama.

Dalam konteks kekinian, image madrasah telah berubah. Madrasah tidak lagi menjadi sekolah Islam yang hanya diminati oleh kalangan menengah ke bawah. Melainkan sudah banyak diminati oleh masyarakat dari golongan menengah ke atas. Hal ini disebabkan munculnya madrasah elit yang sejajar dengan sekolahsekolah umum.

3. Sekolah Islam

Sejak awal abad ke-20 gagasan modernisasi Islam menemukan momentum. Pendidikan direalisasikan dengan pendirian lembaga-lembaga pendidikan modern. Gagasan tersebut menuntut adanya modernisasi sistem pendidikan Islam. Perkembangan mencolok elite Muslim yang dikenal sebagai "sekolah Islam". Sekolah-sekolah itu mulai menyatakan diri secara formal dan diakui oleh kalangan Muslim sebagai "sekolah unggulan" atau sekolah Islam unggulan. Sekolah-sekolah tersebut dapat dikatakan sebagai sekolah "elite" Islam dikarenakan beberapa hal yang mendasarinya. Menurut

Sanaky (2003), alasan yang melatar belakangi sekolah-sekolah tersebut bersifat elite antara lain dari segi akademis.

Dari perkembangan sekolah-sekolah ini, pemerintah dalam hal ini Departemen Agama dan para ahli pendidikan mulai percaya akan kualitas yang ditawarkan oleh sekolah "elite", "unggulan". Sehingga ke depan perbedaan (dikotomi) antara pendidikan Islam dan pendidikan umum dalam konfigurasi pendidikan nasional harus dipersempit. Pendidikan Islam harus diberikan kesempatan untuk meningkatkan kualitas dan yang seimbang untuk mewujudkan pendidikan bermutu sejajar dengan pendidikan umum.

\section{Peran Lembaga Pendidikan}

Peran lembaga pendidikan Islam di Indonesia sangat signifikan. Hal ini dibuktikan dengan eksistensi lembaga pendidikan islam semenjak masa pra kemerdekaan, kemerdekaan hingga masa reformasi. Dapat dilihat dari peran dan kontribusi lembaga pendidikan Islam dalam berbagai aspek :

1) Aspek pendidikan (pedagogis).

2) Aspek Moral-Spiritual.

3) Aspek sosio-kultural. 


\section{Matematika dan Pembentukan Karakter}

Salah satu cara untuk membangun karakter adalah dengan mengajarkannya dalam bentuk satu mata pelajaran disertai kurikulumnya, sehingga alat evaluasinya pun perlu disediakan dan dirancang tersendiri. Menurut Zarkasyi (Tanpa Nama, 2010), jika ini yang dipilih maka ransel anak sekolah bisa jadi lebih berat dari ransel tentara. Belum lagi jika setiap kesadaran baru selalu dimunculkan dalam bentuk mata pelajaran yang baru. Meskipun dapat ditentukan indikator-indikatornya untuk kemudian diberikan skor (nilai) secara kuantitatif, namun demikian pada dasarnya karakter merupakan sesuatu yang bersifat mengualifikasi pribadi seorang individu. Pendidikan karakter yang terlalu dikuantitatifkan, apalagi diberikan sebagai satu mata pelajaran tersendiri, dikhawatikran lebih mudah terjatuh pada pengutamaan aspek kognitif dan diajarkan sebagai pengetahuan, bukan sebagai sikap dan perbuatan. Hal ini tidak akan berbeda dengan bagaimana pendidikan moral dan agama yang selama ini lebih diajarkan sebagai pengetahuan dan bukan sebagai sikap dan perbuatan yang harus dilakukan sehari-hari, sehingga tidak ada perasaan malu, menyesal dan bersalah saat tidak sholat dan boleh saja mencuri (korupsi) asal tidak ketahuan.

Menciptakan lebih banyak siswa yang menguasai matematika adalah penting. Namun demikian, jika pengalaman sejak kemerdekaan menunjukkan tidak ada peningkatan yang berarti dalam hal jumlah/banyaknya siswa yang mampu belajar matematika, tidak ada salahnya jika pembelajaran matematika sedikit digeser dengan tidak sekedar mengajarkan materi matematika, tetapi juga mendidik untuk membangun dan memahat karakter. Pembelajaran matematika dijadikan sebagai media dan wahana untuk pembentukan karakter tersebut. Dengan melekatkan pendidikan karakter dalam pembelajaran matematika, maka pembelajaran matematika tidak lagi untuk mendukung pengembangan ranah kognitif saja tetapi juga mengembangkan ranah afektif dan psikomotorik.

Pembelajaran matematika yang diberikan selama dua belas tahun dari sejak SD sampai dengan SMA dan dengan porsi jam pembelajaran yang paling banyak, tentunya akan menjadi wahana yang tepat untuk memahatkan berbagai karakter pada peserta didik. Jika pembelajaran matematika di Indonesia masih belum seperti di Rumania seperti perasaan yang diungkapkan seorang sopir taksi di sana (Preston, 2005: 83), "Di Rumania, ketika orang tahu kau 
7 | al-Khwarizmi, Volume III, Edisi 2, Oktober 2015, Hal. 1 -8. seorang matematikawan, orang tersebut akan bilang, 'Aku pun dulu pintar matematika. Matematika adalah mata pelajaran favoritku'. Demikianlah keadaannya", maka memahatkan karakter melalui pembelajaran matematika perlu dilakukan. Setidaknya, jika seorang siswa tidak begitu gemilang dalam matematika, atau benar-benar gagal, siswa tersebut masih bisa menyerap karakterkarakter yang dapat ditumbuhkan dalam pembelajaran matematika, dengan tetap percaya diri menyatakan bahwa matematika bukanlah pelajaran yang tidak dapat diselesaikan, meskipun yang menyatakannya pada akhirnya tidak harus menjadi matematikawan atau professor matematika. Kasus tersebut menggambarkan bagaimana pembelajaran matematika berhasil menanamkan kepercayaan diri pada mereka yang pernah belajar matematika.

Jika selama ini pembelajaran matematika lebih dominan pada ranah kognitif, maka sudah saatnya untuk mengeksplorasi ranahranah lainnya, salah satunya dapat dilakukan dengan memahatkan karakter melalui pembelajaran matematika. Pembelajaran matematika di kelas dapat dilakukan dengan mendorong siswa untuk melakukan refleksi dan penghayatan. Dengan cara seperti ini, sesungguhnyalah pembelajaran matematika dapat menanamkan dan menguatkan motivasi, apresiasi atau penghargaan siswa terhadap matematika, kontribusi siswa dalam pembelajaran, interest (minat kuat), beliefs (sikap mental yakin), confidence (sikap mental percaya) dan perseverance (ketekunan, kekuatan hati, kegigihan). Hal-hal yang seperti ini selama ini telah hilang dalam pelaksanaan pembelajaran matematika di ruang kelas.

\section{PENUTUP}

Pembangunan karakter tidak bisa dilaksanakan secara instan, akan tetapi perlu waktu yang panjang untuk membentuknya. Salah satu komponen yang berperan penting dalam upaya besar tersebut adalah pembinaan karakter generasi muda bangsa Indonesia sesuai dengan Pancasila, khususnya karakter positif bangsa yang harus terus ditumbuh-kembangkan untuk memperkuat kemampuan adaptif dari daya saing bangsa sehingga dapat menjadi bangsa yang mandiri di era globalisasi. Peran penting dari generasi muda Indonesia dalam pembangunan karakter adalah sebagai character enabler, character builders dan character engineer. Meskipun untuk menjalankan ketiga peran tersebut, generasi muda masih membutuhkan dukungan serta bantuan dari seluruh elemen bangsa termasuk pemerintah, namun esensi utama dari pembangunan karakter bangsa Indonesia menuju bangsa mandiri adalah 
pentingnya peran generasi muda sebagai komponen bangsa yang paling strategis posisinya dalam memainkan proses transformasi karakter dan tata nilai Pancasila di era globalisasi.

\section{DAFTAR PUSTAKA}

Alaydroes, Fahmi. Liputan Media. From: http://www.pksanz.org/pkspedia/index.php, akses Jum'at 6/6/2008).

Badrun, Ubedilah. Pesantren dan Kepemimpinan Nasional. From: http://ubed-centre.blogspot.com , akses 16/6/2008

Ernest, Paul (1991): The Philosopy of Mathematics Education. The Palmer Press. London.

Fahrurozi. Resensi Buku: Menata Ulang Konsep dan Praktik Pendidikan Islam. From: http://www.MSI-UII.Net,akses, Sabtu,7/6/2008, jam 11.27.

Gladwell, Malcolm (2009): Outliers: Rahasia di Balik Sukses. PT Gramedia Pustaka Utama. Jakarta.

Gravemeijer, K.P.E. (1994): Developing Realistic Mathematics Education. CD- $\beta$ Press. Utrecht.

Hamidah,Kamila. Sejarah Pesantren dan Radikalisme Islam. http://hildaku.blog.com/ diakses Jum'at 6/6/2008 jam 11.23.

Hasbullah. (1996). Sejarah Pendidikan Islam di Indonesia Lintas Sejarah Pertumbuhan dan Perkembangan. Jakarta: PT. Raja Grafindo Persada

Ihsan, Hamdani \& Fuad. (2007). Filsafat Pendidikan Islam.Bandung: Pustaka Setia.

Megawangi, Ratna (2007): Semua Berakar pada Karakter. Lembaga Penerbit FE-UI. Jakarta.

Preston, Richard., et al. (2005): Gunung Pi Kisah-Kisah Matematika Paling Asyik. Banana Publisher. Depok. 